\title{
Genetic Instability in Paediatric and Adult Brain Tumours
}

\author{
Marta Viana-Pereira ${ }^{1,2}$, Chris Jones ${ }^{3}$ and Rui M. Reis ${ }^{1,2,4}$ \\ ${ }^{1}$ Life and Health Sciences Research Institute (ICVS), \\ School of Health Sciences, University of Minho, Braga, \\ ${ }^{2} I C V S / 3 B$ 's - PT Government Associate Laboratory, \\ Braga/Guimarães, \\ ${ }^{3}$ The Institute of Cancer Research, Sutton, \\ ${ }^{4}$ Molecular Oncology Research Center, Barretos \\ Cancer Hospital, Barretos, São Paulo, \\ 1,2Portugal \\ 3UK \\ ${ }^{4}$ Brazil
}

\section{Introduction}

\subsection{Brain tumours in children and adults}

Primary Central Nervous System (CNS) tumours are considered to be those that originate in the CNS and usually remain there. Primary CNS tumours, despite not leading the cancer frequency rates, rank first among cancer types for the average years of life lost (Burnet et al., 2005). By contrast with other malignancies, where research has lead to the establishment of more successful treatment options, the diagnosis of a CNS tumour, particularly the more malignant histological types, still has devastating effects on the patients and their relatives, not only due to the dismal prognosis of these tumours with extremely high rates of mortality, but also to the great morbidity that actual treatment options cause (Laughton et al., 2008; Mulhern et al., 2004; Silber et al., 1992).

The estimated annual worldwide age-standardized incidence of malignant primary CNS tumours is 3.5 per 100,000 people, which represents more than 200,000 cases. The rate is slightly higher in males (3.9 per 100,000 people per year) than in females (3.1 per 100,000 people per year) (Ferlay et al., 2008). The frequency of brain tumours is also higher in more developed countries (5.2 per 100,000 people per year) compared to less developed countries (3.0 per 100,000 people per year), probably due to diagnostic advances, as well as access to adequate health care in the developed regions (Ferlay et al., 2008; Wrensch et al., 2005). Similarly, estimated annual global age-standardized mortality of malignant primary CNS tumours is higher in males ( 3.0 per 100,000 people) than in females ( 2.2 per 100,000 people), with higher rates also in more developed countries (3.2 per 100,000 people) than in less developed regions (2.3 per 100,000 people) (Ferlay et al., 2008). The median age of diagnosis for all primary CNS tumours is 57 years, however the histology-specific median age ranges from 9 to 70 years ( Central Brain Tumor Registry of the United States [CBTRUS], 2010). 
In children, $\mathrm{CNS}$ tumours are the second most frequent malignancy after leukaemia and are therefore the most common solid tumours in childhood (Jemal et al., 2009). An estimated 3,750 new cases of childhood primary non-malignant and malignant CNS tumours are expected to be diagnosed in the United States each year. This number reflects an annual incidence rate of 4.5 cases per 100,000 people. As in adults, the rate is higher in males (4.7 cases per 100,000 people) than in females (4.3 cases per 100,000 people) (CBTRUS, 2010). Importantly, malignant brain tumours are the leading cause of cancer-related death in the childhood (Rickert \& Paulus, 2001).

Pathologically, CNS tumours are generally classified according to the World Health Organization (WHO) criteria (Louis et al., 2007). There are a wide range of CNS histological entities, classified according to the cell morphology and the degree of malignant behaviour. The WHO classification (Louis et al., 2007) includes a grading scheme that is a reference for predicting the biological behaviour of the tumour. Grade I tumours generally have a low proliferative potential and the possibility of cure after surgical resection, whilst grade IV tumours are histologically malignant, mitotically active and necrotic, and are associated with rapid disease evolution contributing to the high rates of mortality and morbidity among malignant brain tumour patients. The incidence of different histological types of brain tumours varies across specific age groups (Maity et al., 2004); accordingly, the regions of the brain mostly affected in paediatric and adult tumours are also different. In adults and older children, brain tumours are mostly supratentorial (cerebrum), whereas in young children they are more commonly infratentorial (cerebellum) (Gottardo \& Gajjar, 2008). This chapter will focus on malignant CNS tumours, more particularly supratentorial high-grade gliomas (WHO grades III and IV) and cerebellar medulloblastomas (grade IV), which are the most common malignant CNS tumours of adults and children, respectively.

Brain tumour aetiology is thought to be multifactorial and is likely to vary by tumour type. There is a likely connection between genetics and environment, meaning that particular genetic susceptibilities lead to increased vulnerability to environmental factors. The only proven exogenous environmental cause of brain tumours, in children or adults, is ionizing radiation, often seen in the setting of previous radiation therapy for the treatment of a former malignancy (Baldwin \& Preston-Martin, 2004; Bondy et al., 2008; Ohgaki \& Kleihues, 2005; Pettorini et al., 2008; Wrensch et al., 2005). Genetic susceptibility to brain tumours comes from rare syndromes and polymorphisms, specifically in pathways thought to be involved in the process of brain tumour formation. Familial tumour predisposition syndromes are associated with germline mutations, typically in tumour suppressor genes, which confer an increased susceptibility of individuals to tumour formation from childhood until their adult life (Ullrich, 2008). Some of the major syndromes associated with highgrade gliomas or medulloblastomas (with genes affected by germline mutations) are neurofibromatosis type 1 (NF1), Li-Fraumeni syndrome (TP53) and Turcot syndrome (APC and MLH1/PMS2/MSH2/MSH6) (complete list in Table 1).

\subsection{High-grade glioma}

The majority of CNS tumours in all age groups are gliomas. The estimated annual incidence rate of gliomas in the United States is 6.0 per 100,000 people. Overall, the broad category of gliomas accounts for $36 \%$ of all CNS tumours and $81 \%$ of malignant lesions. In young adults (20-34 years), gliomas represent $39 \%$ of all CNS tumours and $86 \%$ of malignant tumours; in adolescents (15-19 years), $45 \%$ of all CNS tumours and $81 \%$ of malignant; whereas in 


\begin{tabular}{llll}
\hline $\begin{array}{l}\text { Syndrome } \\
\text { Neurofibromatosis } \\
\text { Type 1 }\end{array}$ & NF1 & $\begin{array}{l}\text { CNS Tumour (e.g.) } \\
\begin{array}{l}\text { Astrocytoma, } \\
\text { neurofibroma, optic } \\
\text { nerve glioma }\end{array}\end{array}$ & $\begin{array}{l}\text { Other Clinical } \\
\text { Manifestations (e.g.) }\end{array}$ \\
\hline $\begin{array}{l}\text { Neurofibromatosis } \\
\text { Type 2 }\end{array}$ & NF2 & $\begin{array}{l}\text { Skiné-au-lait spots; } \\
\text { axillary freckling; other } \\
\text { tumours }\end{array}$ \\
\hline $\begin{array}{l}\text { Tuberous sclerosis } \\
\text { Li-Fraumeni } \\
\text { syndrome }\end{array}$ & TSC1, TSC2 & $\begin{array}{l}\text { Giant cell astrocytoma } \\
\text { Astrocytoma, } \\
\text { medulloblastoma }\end{array}$ & $\begin{array}{l}\text { Posterior lens opacities, } \\
\text { retinal hamartoma }\end{array}$ \\
\hline Turcot & TP5 & Other tumours \\
\hline Gorlin & $M L H 1, P M S 2$, & $\begin{array}{l}\text { Medulloblastoma; } \\
\text { glioblastoma }\end{array}$ & $\begin{array}{l}\text { Skin café-au-lait spots, } \\
\text { colorectal polyps }\end{array}$ \\
\hline
\end{tabular}

Table 1. Familial syndromes and genes involved causing increased risk of gliomas and medulloblastomas. Adapted from (Louis et al., 2007).

children less than 15 years the frequency of gliomas is higher (56\%), but they only account for $74 \%$ of malignant tumours (CBTRUS, 2010). The incidence rates of gliomas by histology varies among age-specific groups; in children and adolescents grade I gliomas are the most common tumours, whereas in older patients grade IV gliomas have the highest incidence (CBTRUS, 2010). The treatment of low-grade gliomas with surgical resection alone allows in most instances the possibility of cure. High-grade gliomas by contrast remain a difficult therapeutic challenge with a poor prognosis. Conventional treatment includes surgery, radiotherapy and chemotherapy, however despite improving survival times and quality of life, current therapeutic regimens are still unable to effect a cure. In malignant histologies, tumour cells infiltrate into the surrounding brain and are generally not completely removed by surgery, which coupled with the fact that these remaining cells are often resistant to radio- and chemotherapy are the main reasons for the therapeutic failure in high-grade gliomas (Imbach, 2006). Similarly in children, surgery plays a major role in the treatment of gliomas, with the extent of tumour resection the most important prognostic factor in this age group. For the more malignant subtypes, focal radiation is used as first line adjuvant therapy, except in infants (Hargrave, 2009; Imbach, 2006). Both in adult and paediatric populations, histological type and grade of the tumour, anatomic location, extent of surgical resection, patient's age, whether radiotherapy is applied, and some chemotherapy protocols have been consistently considered prognostic factors (Stewart \& Cohen, 1998; Wrensch et al., 2005).

The major subtypes of gliomas are astrocytomas, oligodendrogliomas and the mixed lineage, oligoastrocytomas.

Astrocytoma represents a highly heterogeneous histological group of neoplasms. They represent about $75 \%$ of all gliomas and can occur in most parts of the brain, and are the most frequent gliomas of childhood (CBTRUS, 2010). While malignant astrocytomas comprise only $2 \%$ of all adult tumours, their malignant nature makes them the fourth greatest cancerrelated death (Davis et al., 1998). The different histological types of astrocytoma, grade I pilocytic, grade II diffuse, grade III anaplastic and grade IV glioblastoma vary in frequency, age and gender distribution, location within the brain and clinical features. The major malignant subtypes, anaplastic astrocytoma and glioblastoma, account respectively for $8 \%$ 
and $51 \%$ of all gliomas, with glioblastoma representing $80 \%$ of malignant tumours (CBTRUS, 2010; Imbach, 2006; Louis et al., 2007; Reifenberger et al., 2006; Weingart et al., 2006). High-grade glioma may arise de novo, and are designated primary tumours, or may be considered secondary tumours developing from lower grade lesions. Whereas the great majority of adults with diffuse astrocytoma experience malignant transformation to grade III and finally to grade IV astrocytoma, the long-term risk of malignant transformation in histologically identical neoplasms in children is less than $10 \%$ (Broniscer et al., 2007). Nevertheless, the majority (about 95\%) of glioblastomas are primary tumours, develop very rapidly in elderly patients (mean 62 years) after a short clinical history and present a poorer prognosis (Louis et al., 2007), whereas secondary glioblastoma mostly develop in younger patients below the age of 45 (Louis et al., 2007). Due to its invasive nature, glioblastoma cannot be completely resected and despite progress in radio- and chemotherapy, less than half of the patients survive more than a year, making glioblastoma the CNS tumour with worse prognosis, for both paediatric and adult patients (Louis et al., 2007; Reifenberger et al., 2006).

Oligodendroglioma account for a small subset of all gliomas (about 8\%), being predominantly tumours of adulthood, with a peak incidence between the fourth and fifth decade of life, representing only 1-2\% of all CNS tumours in children (CBTRUS, 2010). There are two grades of malignancy for oligodendrogliomas, oligodendroglioma (grade II) and anaplastic oligodendroglioma (grade III), with grading a significant predictor of survival.

Precise data on the incidence of oligoastrocytoma are not available, but reported frequencies vary from $1-20 \%$ of all gliomas, with the higher percentage thought to be overestimated due to a consultation bias. These tumours arise preferentially in the cerebral hemispheres and mainly occur in the fifth decade of life (Bromberg \& van den Bent, 2009; Louis et al., 2007; Reifenberger et al., 2006; van den Bent et al., 2008). Similar to oligodendrogliomas, these tumours can also be divided in two grades of malignancy.

\subsection{Medulloblastoma}

Medulloblastoma represents a highly malignant, invasive embryonic tumour, and is the most common malignant CNS tumour in children, accounting together with other embryonic tumours for about $1.5 \%$ of all primary CNS tumours (CBTRUS, 2010), representing $12-25 \%$ of childhood brain tumours and only about $0,5-1 \%$ of all brain neoplasms in adults (Imbach, 2006; Sarkar et al., 2005; Taylor, 2006). The peak age incidence is 9 years, with $70 \%$ of all medulloblastomas occurring in patients less than 16 years of age. In adulthood, $80 \%$ of medulloblastomas arise before the fourth decade of life and rarely occur after the fifth decade. About $65 \%$ of patients are male (Louis et al., 2007; Reifenberger et al., 2006; Taylor, 2006). The annual incidence of medulloblastoma has been estimated at 0.5 per 100,000 children less than 15 years (CBTRUS, 2010; Reifenberger et al., 2006). Medulloblastoma presents predominantly neuronal differentiation. It is composed of densely packed small round blue cells with carrot-shaped hyperchromatic nuclei, possibly presenting neuroblastic rosettes which are associated with marked nuclear pleomorphism and high mitotic activity (Huse \& Holland, 2010; Imbach, 2006; Louis et al., 2007; Taylor, 2006). The WHO classification of CNS tumours recognizes at least five different histological types of medulloblastoma: classic (70-85\% of the cases); desmoplastic/nodular $(15 \%$ in paediatric medulloblastoma compared to $30-40 \%$ in adults); anaplastic (about $10-22 \%$ of medulloblastomas); large cell (about $2-4 \%$ of cases) and medulloblastoma with extensive 
nodularity (about 3\%) (Brandes et al., 2009; Imbach, 2006; Louis et al., 2007; Taylor, 2006). There is an heterogeneity among medulloblastoma histologic subtypes which exhibit a highly variable clinical behaviour, with the anaplastic and large cell subtypes being associated with worse prognosis and desmoplastic/nodular medulloblastomas portending a more favourable outcome (Gilbertson \& Ellison, 2008; Huse \& Holland, 2010; Imbach, 2006). About $30 \%$ of the medulloblastoma patients, particularly paediatric tumours, present metastasis via the cerebrospinal fluid pathways at diagnosis, whereas spread outside the CNS is a rare event (Carrie et al., 1994; Frost et al., 1995; Reifenberger et al., 2006). Clinical prognostic factors include tumour size, presence of metastasis, age, and amount of tumour resected (Imbach, 2006). Stratification of medulloblastoma involves distinguishing high-risk and standard-risk patients, with high-risk patients those aged less than 3 years, with incomplete surgical resection of the tumour and/or with disseminated disease (Dubuc et al., 2010; Imbach, 2006; Louis et al., 2007). Significant advances have been made in the treatment of childhood medulloblastoma, with the 5-year survival raised to $60 \%$ for high-risk disease and $80 \%$ for standard-risk tumours, however the long-term side effects of the treatment modalities applied can be severe. Actual treatment includes maximal safe surgical resection and the use of combined radio- and chemotherapy for children older than 3 years. Most therapeutic approaches for high-risk patients include relatively high doses of craniospinal radiotherapy and aggressive chemotherapeutic regimens (Hargrave, 2009; Imbach, 2006). The treatment of infants with medulloblastoma remains highly problematic as radiation therapy is especially damaging for the developing brain of very young children.

\section{Genetic instability of malignant brain tumours}

Cancer cells usually harbour mutations in oncogenes and tumour suppressor genes. These may play a role in key cellular processes such as proliferation, apoptosis or angiogenesis. Oncogenes are genes whose deregulated activation through mutation, translocation, amplification or over-expression promotes tumorigenesis. Tumour suppressors, on the other hand, play an inhibitory role, and can be inactivated in cancer through mutation, deletion, methylation or transcriptional repression. Genomic instability present in cancer cells occurs mainly through chromosomal instability (CIN) or microsatellite instability (MSI), together with increased frequencies of molecular alterations in cancer regulatory genes (Negrini et al., 2010; Nigg, 2005). CIN refers to the high rate by which chromosome structure and number (by gains or losses) changes over time in cancer cells compared with normal cells and MSI is characterized by the expansion or contraction of the number of oligonucleotide repeats present in microsatellite sequences (Venkatesan \& Loeb, 2005).

\subsubsection{Patterns of copy number change}

$\mathrm{CIN}$ is characterised by an increased frequency of chromosomal alterations, resulting in gains, losses, deletions, insertions, translocations, amplifications, and rearrangements. Nearly all human tumours display the CIN phenotype and consequently aneuploidy. Tumours with the CIN usually harbour mutations in oncogenes and/or tumour suppressor genes, many of which are involved in the regulation of transcription (Nigg, 2005). During the last decade, the use of genome-scale profiling techniques to identify the key genetic alterations underlying different tumour types allowed fundamental findings about the drivers of oncogenesis, providing the rationale for specific targeted therapies in these malignancies. The first studies 
using large-scale genome profiling techniques to identify the key genetic alterations of brain tumours were only recently published (Kool et al., 2008; Parsons et al., 2008; The Cancer Genome Atlas Research Network [TCGA], 2008; Thompson et al., 2006). Nevertheless, the number of such studies have been increasing on the past few years, with the first studies in paediatric glioma patients starting to emerge (Barrow et al., 2011; Bax et al., 2010; Paugh et al., 2010; Qu et al., 2010; Schiffman et al., 2010; Zarghooni et al., 2010).

\subsubsection{High-grade glioma}

Comprehensive mapping of the genome of adult glioblastoma has identified common regions of chromosomal instability and gene expression signatures, identifying frequently dysregulated molecular pathways (Bredel et al., 2005; de Tayrac et al., 2009; Gardina et al., 2008; Kotliarov et al., 2006; Maher et al., 2006; Nigro et al., 2005; Parsons et al., 2008; TCGA, 2008). The number of such studies specifically addressing childhood high-grade glioma has until recently been much lower. Nevertheless, several works specifically addressing these paediatric tumours, from ours and others groups, are beginning to emerge, providing increasing evidence that the paediatric high-grade glioma genome has certain key differences from that of histologically similar adult tumours (Barrow et al., 2011; Bax et al., 2010; Paugh et al., 2010; Qu et al., 2010; Rao et al., 2010; Rickert et al., 2001; Schiffman et al., 2010; K.K. Wong et al., 2006; Zarghooni et al., 2010).

These studies have demonstrated that the retinoblastoma (RB), p53 and RTK/PI3K/MAPK pathways are commonly disrupted in adult and paediatric glioblastomas through various genetic mechanisms (TCGA, 2008; Parsons et al., 2008). Nevertheless, our data has demonstrated that paediatric tumours show deregulation of these core pathways by copy number alterations in less than half the frequency of that reported for adult tumours: $25 \%$ RTK/PI3K/MAPK, 19\% p53 and 22\% RB versus 59\%, 70\% and $66 \%$, for adult glioblastoma (Figure 1) (Bax et al., 2010; TCGA, 2008). Even though isolated cases presented clear genomic events linked to activation of the sonic hedgehog ( $\mathrm{SHH}$ ) and Notch pathways activation, there is no evidence of consistently targeted pathways in paediatric high-grade gliomas. Nevertheless, low-frequency amplifications in childhood tumours included genes involved in cell cycle progression (CCND2, CDK4, MYC, and MYCN), receptor tyrosine kinases (RTKs) and ligands (EGFR, MET, IGF1R, PDGFB, and NRG1), members of the PI3K/MAPK pathway (PIK3C2B, PIK3C2G, PIK3R5, KRAS, AKT1, and S6K1), and p53 pathway regulation $(M D M 4)$, some of them known to be deregulated also in adult glioblastoma (Figure 2) (Bax et al., 2010; Paugh et al., 2010). In addition, homozygous deletions of tumour suppressor genes of known importance within the adult glioblastoma core signalling pathways included CDKN2C, PTEN, RB1, TP53, and TP73 (Figure 1) (TCGA, 2008; Parsons et al., 2008), albeit at considerably lower frequencies in paediatric versus adult tumours. These numerous low-frequency amplifications and deletions identified in paediatric high-grade gliomas, such as $M Y C / M Y C N, C C N D 2, K R A S$, and CDKN2C, suggest that paediatric high-grade gliomas may be molecularly more similar to secondary adult glioblastomas (Beroukhim et al., 2007; Maher et al., 2006).

At the gross chromosomal level, paediatric glioblastomas can be distinguished from adult tumours by the more frequent gain of chromosome $1 \mathrm{q}$ and loss of $16 \mathrm{q}$, and the relative scarcity of chromosome 7 gains and 10q losses. The most frequent focal amplifications are also different, with PDGFRA predominant in paediatric and EGFR adult tumours (Table 2). Moreover, paediatric cases without PDGFRA amplification seem to present overexpression of a specific PDGFRA-associated gene signature, which differs from that observed in adult 

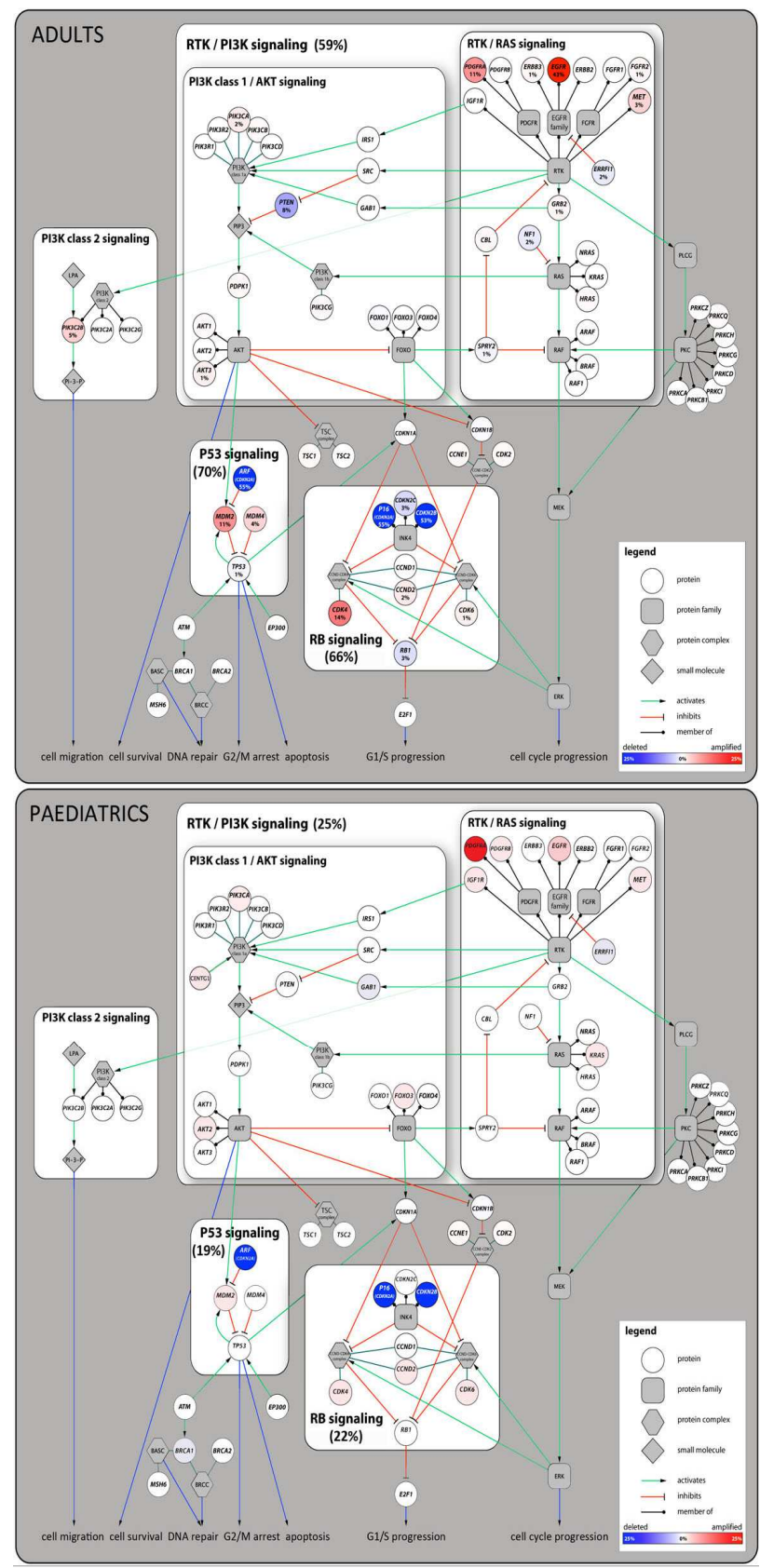

Fig. 1. Copy number alterations in core signalling Pathways in Adult and Paediatric Glioblastoma. RTK/PI3K/MAPK, p53 and RB pathways are more frequently deregulated in adult than in paediatric glioblastomas. Adapted from (Bax et al., 2010; TCGA, 2008). 
tumours with the 4q12 amplification (Bax et al., 2010; Martinho et al., 2009; Paugh et al., 2010; Rickert et al., 2001; K.K. Wong et al., 2006). Even if PDGFRA amplification, $1 q^{+}$and 16q- events are more common in paediatric patients (Qu et al., 2010; Schiffman et al., 2010; Zarghooni et al., 2010), they are also present in a proportion of adult tumours. Similarly there is a small group of paediatric high-grade gliomas containing copy number alterations associated with adult tumours (EGFR amplification, 7+, 10q-) (Bax et al., 2010; Paugh et al., 2010). The deletion of $C D K N 2 A / C D K N 2 B$ is among the most frequent focal events found in paediatric high-grade gliomas, nevertheless it is even more commonly present in adult tumours (Table 2) (Bax et al., 2010; TCGA, 2008; Paugh et al., 2010). In adults, secondary glioblastomas show overexpression or amplification of PDGFRA but rarely contain EGFR aberrations.

\begin{tabular}{llll}
\hline Region & $\begin{array}{l}\text { Paediatric Glioblastoma } \\
(\mathrm{n}=46)\end{array}$ & $\begin{array}{l}\text { Adult Glioblastoma } \\
(\mathrm{n}=189)\end{array}$ & $P$ \\
\hline Gains & & & \\
$1 \mathrm{q}$ & $30 \%$ & $9 \%$ & 0.001 \\
7 & $13 \%$ & $74 \%$ & $<0.001$ \\
\hline Losses & & & 0.05 \\
$1 \mathrm{p}$ & $9 \%$ & $2 \%$ & $<0.001$ \\
$4 \mathrm{q}$ & $22 \%$ & $2 \%$ & $<0.05$ \\
$9 \mathrm{p}$ & $17 \%$ & $33 \%$ & $<0.001$ \\
$10 \mathrm{q}$ & $35 \%$ & $80 \%$ & 0.003 \\
$16 \mathrm{q}$ & $24 \%$ & $7 \%$ & 0.2 \\
\hline Focal amplifications & & & $<0.001$ \\
\hline PDGFRA & $16 \%$ & $11 \% *$ & $<0.001$ \\
EGFR & $4 \%$ & $43 \% *$ & \\
\hline Focal deletions & & & \\
CDKN2A & $20 \%$ & $55 \% *$ & \\
\hline
\end{tabular}

${ }^{*} \mathrm{n}=206$ tumours

Table 2. Summary of copy number changes in Paediatric and Adult Glioblastoma. Adapted from (TCGA, 2008; Paugh et al., 2010).

Recently, missense mutations in IDH1 were found in a significant number of adult glioblastomas that tend to occur mostly in younger patients with more protracted clinical courses (Parsons et al., 2008). These mutations were found exclusively on the R132 residue in the active site region of the protein (Parsons et al., 2008; Yan et al., 2009). Interestingly, a separate group of gliomas harbour mutations in the IDH1 homologue IDH2 at the analogous residue (R172). Further investigations have shown that mutations in IDH1 and IDH2 are present in high proportions of grade II and III astrocytic, oligodendroglial and mixed tumours (72 to $100 \%$ ) along with secondary glioblastomas (up to $85 \%$ ), but are largely absent in primary glioblastomas (5\%) (Hartmann et al., 2009; Ichimura et al., 2009; Parsons et al., 2008; Watanabe et al., 2009; Yan et al., 2009). Additionally, IDH mutations are associated with other genomic abnormalities that are typically seen in gliomas, such as TP53 mutation in low-grade astrocytoma, and $1 \mathrm{p} / 19 \mathrm{q}$ deletion in oligodendrogliomas; they are also mutually exclusive with EGFR amplification and chromosome 10 loss (Sanson et al., 2009; Watanabe et al., 2009; Yan et al., 2009). These findings suggest that, although IDH mutations 
probably contribute to the early evolution of low-grade gliomas, remaining in the highergrade lesions, they seem to have no role in the underlying biology of primary glioblastoma. Importantly, these IDH1 hotspot mutations are not found in childhood tumours (Balss et al., 2008; Yan et al., 2009), biologically distinguishing paediatric high-grade gliomas from adult secondary glioblastoma. Nevertheless, IDH1 mutations was recently found in 7 of the 20 high-grade gliomas from older children (14-18 years) and reported to be associated with a favourable prognosis, as observed in adults (Pollack et al., 2010a).

Oligodendrogliomas harbour specific copy number alterations related to response to therapy or prognosis, however a comparison between adult in paediatric populations is difficult, as paediatric oligodendrogliomas are extremely rare neoplasms. Still, up to $80 \%$ of adult tumours show combined loss of chromosomes $1 \mathrm{p}$ and $19 \mathrm{q}$, associated with increased chemosensitivity to treatment and favourable clinical outcome (Smith et al., 2000, 1999), whereas deletion of these regions are rare and did not seem to anticipate a survival advantage in paediatric high-grade gliomas (Kreiger et al., 2005; Pollack et al., 2003).

Another feature of childhood high-grade gliomas that is almost entirely absent from adult tumours is the occurrence of very few or even no detectable copy number alterations in paediatric tumours (Bax et al., 2010; Paugh et al., 2010). This stable genomic profile is independent of histologic grade or type, and seems to confer an improved survival in highgrade glioma patients, in contrast to those patients with an amplifier genomic profile, who do significantly worse (Bax et al., 2010).

\subsubsection{Medulloblastoma}

Similarly to glial tumours, studies of genomic copy number alterations analysing large cohorts of paediatric and adult medulloblastomas have recently begun to emerge (Kool et al., 2008; Thompson et al., 2006; Korshunov et al., 2010).

The most frequent and consistent genetic event reported in medulloblastoma is the partial or complete loss of the chromosome $17 \mathrm{p}$, often in association with gain of chromosome $17 \mathrm{q}$ (resulting in the isochromosome 17q: $\mathrm{i}(17) \mathrm{q})$, occurring in approximately $30-50 \%$ of the medulloblastomas (Biegel et al., 1997; Bigner et al., 1988; Cogen \& McDonald, 1996; Lamont et al., 2004; Nicholson et al., 2000; Steichen-Gersdorf et al., 1997; Capodano et al., 1994). Although the precise mechanism by which this genomic abnormality contributes to tumorigenesis and its prognostic importance remain unclear, the common deletion region of 17p13.2-13.3 includes several confirmed and putative tumour suppressor genes, including TP53 (Huse \& Holland, 2010). Together with the deletion of 17p, MYC amplification is a molecular prognostic factor of medulloblastoma (Imbach, 2006). Genomic amplifications of MYCN and MYC were described as characteristics of a subset of clinically aggressive medulloblastomas that tend to exhibit large cell/anaplastic histological features (Aldosari et al., 2002; Tomlinson et al., 1994).

Recently, Korshunov and colleagues (Korshunov et al., 2010) compared a large series of adult and paediatric subsets of tumours, using array-based comparative genomic hybridization (aCGH) (34 adult and 101 paediatric patients) and validating the results in an independent series (112 adult and 303 childhood patients) by fluorescent in situ hybridization (FISH) analysis. Although frequencies of loss of $17 \mathrm{p}$ (either isolated or via $i(17) q$ formation) were similar in both populations, isolated gains of $17 q$ were significantly more frequent in children than adult patients, with monosomy of chromosome 17 exclusively found in adults (Table 3) (Korshunov et al., 2010). Additionally, amplifications of MYC/MYCN prevailed in the paediatric cohort, whereas amplification of CDK6 (at 
7q21.3), was frequently present in adult tumours and absent in paediatric medulloblastomas. Of note is that both MYC/MYCN and CDK6 amplifications were associated with poor survival in paediatric and adult populations, respectively. Besides chromosome $17 \mathrm{q}$, alterations on additional chromosome arms were shown to be significantly different between adult and paediatric medulloblastoma. Gains of chromosome $3 q, 4$ and 19 more frequently found in the adult tumours, while gains of 1q, 2 and 7 and loss of $16 \mathrm{q}$ was more abundant in children. The frequency of chromosome 6 deletions was similar across adult and childhood medulloblastoma, however the patterns of aberration were different, with complete loss of the chromosome and absence of concomitant aberrations frequently more present in paediatric medulloblastoma (Korshunov et al., 2010). This may explain the reason why the prognostic value of chromosome 6 deletion, a well established marker for favourable outcome in medulloblastoma (Clifford et al., 2006; Pfister et al., 2009; Thompson et al., 2006), was not found to be statistically significant for adult cases (Korshunov et al., 2010). A summary of the results from the validation cohort is presented on Table 3.

\begin{tabular}{|c|c|c|c|}
\hline Region & $\begin{array}{l}\text { Paediatric Medulloblastoma } \\
\qquad(\mathrm{n}=303)\end{array}$ & $\begin{array}{l}\text { Adult Medulloblastoma } \\
\qquad(\mathrm{n}=112)\end{array}$ & $P$ \\
\hline \multicolumn{4}{|l|}{ Gains } \\
\hline $1 q$ & $24 \%$ & $9 \%$ & $<0.001$ \\
\hline 2 & $15 \%$ & $6 \%$ & 0.02 \\
\hline $6 q$ & $11 \%$ & $3 \%$ & * \\
\hline 7 & $33 \%$ & $14 \%$ & $<0.001$ \\
\hline $17 q$ & $17 \%$ & $2 \%$ & ** \\
\hline \multicolumn{4}{|l|}{ Losses } \\
\hline $6 q$ & $12 \%$ & $15 \%$ & * \\
\hline $17 p$ & $4 \%$ & $4 \%$ & $* *$ \\
\hline \multicolumn{4}{|l|}{ Focal amplifications } \\
\hline CDK6 & $0.3 \%$ & $8 \%$ & $<0.001$ \\
\hline MYC/MYCN & $14 \%$ & $3 \%$ & $<0.001$ \\
\hline $\begin{array}{l}\text { Other Alterations } \\
\mathrm{i}(17) \mathrm{q}\end{array}$ & $39 \%$ & $32 \%$ & $* *$ \\
\hline
\end{tabular}

${ }^{*} P=0.02$ for total Chromosome 6 aberrations; ${ }^{* *} P<0.001$ for total Chromosome 17 aberrations

Table 3. Summary of copy number changes in Paediatric and Adult Medulloblastomas (validation set of adult tumours by FISH analysis). Adapted from (Korshunov et al., 2010).

\subsection{Microsatellite Instability}

DNA is continuously exposed to numerous different insults, endogenous and exogenous, that can ultimately result in DNA mutation and alteration of cell behaviour. DNA repair mechanisms are therefore essential for maintaining DNA integrity and preventing tumorigenesis ( $\mathrm{Li}, 2008$; Ljungman, 2010). Consequences of the failure of these molecular pathways are well illustrated in colorectal cancer, mainly HNPCC where it is present in about $90 \%$ of the tumours. In these cancers, mismatch repair (MMR)-deficient cells adopt a mutator phenotype in which there is a significant increase in cellular mutation rates (Loeb, 1991; Marra \& Jiricny, 2005). The most obvious molecular signature of this mutator phenotype is the presence of microsatellite instability (MSI) (Fishel \& Kolodner, 1995). 
The MMR system is the major pathway responsible for repairing base-base mispairs and short insertion/deletion loops that arise during DNA replication and as intermediates of homologous recombination (Arana \& Kunkel, 2010; Kunkel \& Bebenek, 2000; Nigg, 2005). Such a mechanism is essential to the cells because the fidelity of replicating DNA polymerases is insufficient to generate an error-free copy of genomic DNA. Single-base substitutions are estimated to arise once in every 104-106 nucleotides incorporated, and MMR reduces the error rate to a range of $10^{-9}$ to $10^{-10}$, which ensures that the human genome can be duplicated without mutations (Kunkel \& Bebenek, 2000). Left unrepaired, these structures will give rise to base-substitution and frameshift mutations, respectively (Arana \& Kunkel, 2010; Kunkel \& Bebenek, 2000; Nigg, 2005). The role of the key factors of the human MMR system, the MutS homologues MSH2, MSH3 and MSH6, and the MutL homologues MLH1 and PMS2, have begun to be elucidated (Jiricny, 2006; Li, 2008; Schofield \& Hsieh, 2003). MSH6 competes for binding to MSH2 with MSH3 (Boland et al., 2008), whilst MLH1 can form heterodimers with PMS2 (Li \& Modrich, 1995), PMS1 (Raschle et al., 1999) or MLH3 (Lipkin et al., 2000); MLH1/PMS2 is the only complex with an essential role in mismatch correction (Nigg, 2005; Shah et al., 2010).

Microsatellites are short DNA sequence repeats that are scattered throughout the human genome (Lander et al., 2001), and whose copy number varies steadily through evolution (Ellegren, 2004). MSI is the expansion or retraction of the number of repeats within the microsatellites and it is assumed to be generated by slippage of DNA polymerases during copying of repeats, representing a hot spot for mutagenesis (Aaltonen et al., 1994; Cahill et al., 1999; Ionov et al., 1993). The classification of MSI more commonly adopted takes into account the number of markers presenting frameshift alterations. MSI tumours are therefore classified as MSI-H when, comparing to germline DNA, two or more markers present allelic shifts, or in the absence of constitutive DNA, at least three markers are altered. When one or two markers present alterations tumours are classified as MSI-L; when all markers are normal tumours are classified as microsatellite stable (MSS) (Buhard et al., 2006; Umar et al., 2004; Y.F. Wong et al., 2006). In parallel with this classification, an alternative qualitative distinction of MSI, which considers the size of the allelic shifts in the markers, has been proposed (Giunti et al., 2009; Oda et al., 2005). Samples presenting small length changes ( $\leq 6$ bp) are designed Type A MSI whereas those with more extreme variations are defined as Type B MSI.

The presence and frequency of MSI in brain tumours is a controversial and poorly studied issue. Previous studies have evaluated the presence of MSI in brain tumours, particularly in gliomas, while in medulloblastomas MSI status has not been properly addressed. Reports in the literature describe the absence or rare incidence of MSI in adult patients, while in children results have been contradictory, with reported frequencies in paediatric gliomas varying between 0 and 44\% (Alonso et al., 2001; Amariglio et al., 1995; Cheng et al., 1999; Dams et al., 1995; Eckert et al., 2007; Izumoto et al., 1997; Kanamori et al., 2000; Leung et al., 1998; Martinez et al., 2005; Sobrido et al., 2000; Vladimirova et al., 2007). Importantly, the methodologies for determining MSI have been highly diverse, making it difficult to draw accurate conclusions (Table 4). To clarify the role of MSI in paediatric versus adult malignant brain tumours, our group has used a highly sensitive and robust panel of MSI markers and studied series of high-grade glioma and medulloblastoma of adult and paediatric samples for the presence of MSI (Viana-Pereira et al., 2009, 2011). In our study of high-grade 


\begin{tabular}{|c|c|c|c|c|c|}
\hline Reference & $\begin{array}{c}\text { Age } \\
\text { (years) }\end{array}$ & $\begin{array}{l}\text { Number of } \\
\text { cases }\end{array}$ & MSI (\%) & Markers & $\begin{array}{c}\text { QMVR or } \\
\text { comparison with } \\
\text { germline DNA }\end{array}$ \\
\hline $\begin{array}{l}\text { Pollack et al., } \\
2010 \text { b }\end{array}$ & $<21$ & 68 & $3(4.4 \%)$ & $\begin{array}{l}\text { Mononucleotide and } \\
\text { Polynucleotide* }\end{array}$ & $\mathrm{N} / \mathrm{A}$ \\
\hline $\begin{array}{l}\text { Maxwell et } \\
\text { al, } 2008\end{array}$ & $\mathrm{~N} / \mathrm{A}$ & 52 & $8(15.4 \%)$ & Mononucleotide & QMVR \\
\hline $\begin{array}{l}\text { Vladimirova } \\
\text { et al., } 2007\end{array}$ & $<18$ & 126 & $4(3.2 \%)$ & Mononucleotide & - \\
\hline \multirow{2}{*}{$\begin{array}{l}\text { Eckert et al., } \\
2007\end{array}$} & $<22$ & 71 & 0 & \multirow{2}{*}{ Mononucleotide } & \multirow{2}{*}{$\mathrm{N} / \mathrm{A}$} \\
\hline & $<22$ & 553 & $1(0.2 \%)$ & & \\
\hline \multirow{2}{*}{$\begin{array}{l}\text { Martinez et } \\
\text { al., } 2005\end{array}$} & $<18$ & 1 & 0 & \multirow{2}{*}{$\begin{array}{l}\text { Mononucleotide and } \\
\text { Polynucleotide }\end{array}$} & \multirow{2}{*}{$\begin{array}{l}\text { Comparison with } \\
\text { germline DNA }\end{array}$} \\
\hline & $>18$ & 108 & $6(5.6 \%)$ & & \\
\hline \multirow{2}{*}{$\begin{array}{l}\text { Alonso et al., } \\
2001\end{array}$} & $<21$ & 102 & $16(15.7 \%)$ & \multirow{2}{*}{ Mononucleotide } & \multirow{2}{*}{ No } \\
\hline & $>21$ & 104 & 0 & & \\
\hline \multirow{3}{*}{$\begin{array}{l}\text { Kanamori et } \\
\text { al., } 2000\end{array}$} & $13-19$ & 6 & $2(33.3 \%)$ & \multirow{3}{*}{$\begin{array}{l}\text { Mononucleotide and } \\
\text { Polynucleotide }\end{array}$} & \multirow{3}{*}{$\begin{array}{l}\text { Comparison with } \\
\text { germline DNA }\end{array}$} \\
\hline & $20-29$ & 8 & 0 & & \\
\hline & $>30$ & 66 & 0 & & \\
\hline $\begin{array}{l}\text { Sobrido et al., } \\
2000\end{array}$ & $\mathrm{~N} / \mathrm{A}$ & 56 & $10(17.9 \%)$ & Polynucleotide & $\begin{array}{l}\text { Comparison with } \\
\text { germline DNA }\end{array}$ \\
\hline
\end{tabular}

${ }^{*} \mathrm{NCI}$ recommended panel of markers (2 mononucleotide markers: BAT26 and BAT25; and 3 dinucleotide markers: D2S123, D5S346 and D17S250)

N/A - not available

Table 4. Summary of relevant studies reporting MSI analysis in brain tumours after the year 2000.

gliomas, the frequency of MSI was significantly higher in paediatric than adult tumours (Viana-Pereira et al., 2011), reflecting the bulk of the previously published data (Alonso et al., 2001; Cheng et al., 1999; Kanamori et al., 2000; Leung et al., 1998; Martinez et al., 2005). On the other hand, in medulloblastomas, no difference was observed in MSI frequency between adult and paediatric tumours, suggesting that the presence of MSI in these tumours is not age-related (Viana-Pereira et al., 2009). Overall, it seems that there are less molecular differences between adult and paediatric medulloblastomas than those reported in highgrade gliomas, in concordance with our MSI data.

One of the key considerations in the assessment of MSI is in the use of mononucleotides versus polynucleotides in the panel of markers used. In our studies we used a pentaplex of quasimonomorphic mononucleotide markers (NR27, NR21, NR24, BAT25 and BAT26), which is currently regarded as the most sensitive panel of markers available, with distinct advantages over the classic National Cancer Institute panel of markers (2 mononucleotide markers: BAT26 and BAT25; and 3 dinucleotide markers: D2S123, D5S346 and D17S250) to the determine MSI in populations of different ethnicities and in different types of human tumours (Buhard et al., 2004; Buhard et al., 2006; Goel et al., 2010; Y.F. Wong et al., 2006). Importantly, the use of quasimonomorphic mononucleotide markers overcomes the need 
for using matching germline DNA, required when using dinucleotide polymorphic markers. Despite this, still there is the need for optimization of the quasi-monomorphic variation range (QMVR) for each marker, as the allelic size estimation for these quasimonomorphic markers can be influenced by the use of specific reagents or the sequencing machine (Goel et al., 2010).

Previous studies have established MSI frequencies in gliomas using polynucleotide markers only, with frequencies ranging from 0 to 37\% (Amariglio et al., 1995; Dams et al., 1995; Izumoto et al., 1997; Sobrido et al., 2000). Including both mononucleotide and polynucleotides repeat markers did not improve consistency, with contrasting results varying between 0 and $44 \%$ in paediatric gliomas cohorts or between 0 and $18 \%$ in adult tumours (Cheng et al., 1999; Kanamori et al., 2000; Leung et al., 1998; Martinez et al., 2005; Pollack et al., 2010b). Using mononucleotides only also provided contradictory results of 0 to $27 \%$ MSI in paediatric gliomas (Alonso et al., 2001; Eckert et al., 2007; Vladimirova et al., 2007). In addition to the heterogeneity of markers used to assess MSI frequency that likely accounts for the majority of variability in the data, many of the previous studies did not refer the establishment of a QMVR (for quasimonomorphic mononucleotide markers) or a direct comparison between tumour and germline DNA (for other markers).

In contrast to colorectal cancer, which presents mainly Type B MSI, we and others have shown that high-grade gliomas harbour Type A MSI (Giunti et al., 2009; Viana-Pereira et al., 2009, 2011). Moreover, we have observed that both MSI-positive medulloblastoma and highgrade glioma presented small length alterations within the microsatellites and hypothesise that this can also contribute for the high variation frequency of MSI in brain tumours reported in the literature (Alonso et al., 2001; Amariglio et al., 1995; Cheng et al., 1999; Dams et al., 1995; Eckert et al., 2007; Izumoto et al., 1997; Kanamori et al., 2000; Leung et al., 1998; Martinez et al., 2005; Sobrido et al., 2000; Vladimirova et al., 2007).

Importantly, the MSI-positive paediatric high-grade glioma mostly presented a stable genomic profile at the chromosomal level, even if microsatellite and chromosomal instability were not mutually exclusive. As mentioned above, the presence of a proportion of tumours with few or absent copy number alterations distinguishes paediatric high-grade gliomas from their adult counterparts and therefore we hypothesise that MSI might represent an alternative form of genetic instability, at least in a proportion of these paediatric tumours with no gross chromosome number alterations.

Mismatch repair deficiencies have been associated with paediatric brain tumours in a hereditary context. Case reports have described MMR germline mutations combined with NF1-like clinical features in children presenting medulloblastoma or high-grade glioma, described as a "mismatch repair-deficiency (MMR-D) syndrome" (summary in Table 5) (Agostini et al., 2005; De Rosa et al., 2000; Giunti et al., 2009; Hegde et al., 2005; Kruger et al., 2008; Menko et al., 2004; Ostergaard et al., 2005; Poley et al., 2007; Roy et al., 2009; Scott et al., 2007; Toledano et al., 2009; Viana-Pereira et al., submitted; Wagner et al., 2003; Wang et al., 1999). Also in our study there was a MSI-H paediatric high-grade glioma with clinical characteristics of NF1 (multiple café-au-lait spots). Even though there was no constitutional DNA available for evaluation of MMR germline mutations, data imply that this patient probably present a MSH6 germline mutation, harbouring a MMR-D syndrome (de Leeuw et al., 2000).

Due to the widespread presence of microsatellites in DNA, mutations are expected to accumulate in the genome of tumour cells due to MMR deficiency, with some alterations 


\begin{tabular}{|c|c|c|c|c|c|}
\hline Family & Malignancy & $\begin{array}{c}\text { Age at } \\
\text { diagnosis }\end{array}$ & $\begin{array}{l}\text { Café-au- } \\
\text { lait spots }\end{array}$ & $\begin{array}{l}\text { Affected } \\
\text { gene }\end{array}$ & Reference \\
\hline 1 & $\begin{array}{l}\text { AML } \\
\text { Medulloblastoma }\end{array}$ & $\begin{array}{l}6 \\
7\end{array}$ & Yes & MLH1 & Wang et al., 1999 \\
\hline 2 & $\begin{array}{l}\begin{array}{l}\text { Anaplastic } \\
\text { oligodendroglioma/ } \\
\text { Colorectal cancer }\end{array} \\
\text { Neuroblastoma }\end{array}$ & $\begin{array}{c}14 / 17 \\
18 \\
13 \\
\end{array}$ & NS & PMS2 & De Rosa et al., 2000 \\
\hline 3 & $\begin{array}{l}\text { Oligodendroglioma } \\
\text { Rectosigmoid carcinoma }\end{array}$ & $\begin{array}{l}10 \\
12 \\
\end{array}$ & Yes & MSH6 & Menko et al., 2004 \\
\hline 4 & Glioblastoma & 8 & Yes & MSH6 & Hegde et al., 2005 \\
\hline 5 & $\begin{array}{l}\text { Duodenal adenocarcinoma } \\
\text { Colonic adenoma } \\
\text { Glioblastoma }\end{array}$ & $\begin{array}{l}16 \\
16 \\
17 \\
\end{array}$ & Yes & PMS2 & Agostini et al., 2005 \\
\hline 6 & $\begin{array}{l}\text { Pilocytic astrocytoma } \\
\text { Lymphoma } \\
\text { Spinal glioblastoma }\end{array}$ & $\begin{array}{c}9 \\
10 \\
2 \\
\end{array}$ & Yes & MSH6 & $\begin{array}{l}\text { Ostergaard et al., } \\
2005\end{array}$ \\
\hline 7 & $\begin{array}{l}\text { Glioblastoma } \\
\text { Wilms tumour }\end{array}$ & $\begin{array}{l}4 \\
4\end{array}$ & Yes & MLH1 & $\begin{array}{l}\text { Wagner et al., } 2003 \\
\text { Poley et al., } 2007\end{array}$ \\
\hline 8 & $\begin{array}{l}\text { Lymphoma } \\
\text { Anaplastic } \\
\text { oligodendroglioma } \\
\text { Medulloblastoma }\end{array}$ & $\begin{array}{l}4 \\
6\end{array}$ & Yes & MSH6? & Poley et al., 2007 \\
\hline 9 & $\begin{array}{l}\text { Medulloblastoma } \\
\text { AML } \\
\text { Colon carcinomas }\end{array}$ & $\begin{array}{c}7 \\
10 \\
13 \\
\end{array}$ & Yes & MSH6 & Scott et al., 2007 \\
\hline 10 & $\begin{array}{l}\text { Glioblastoma } \\
\text { Glioblastoma } \\
\text { Colorectal cancer } \\
\text { Small bowel cancer } \\
\text { Urotel carcinoma } \\
\text { Glioblastoma } \\
\end{array}$ & $\begin{array}{c}6 \\
6 \\
15 \\
15 \\
15 \\
9 \\
\end{array}$ & Yes & PMS2 & Kruger et al., 2008 \\
\hline 11 & Glioblastoma & 10 & Yes & PMS2 & Giunti et al., 2009 \\
\hline 12 & $\begin{array}{l}\text { Glioblastoma } \\
\text { Glioblastoma }\end{array}$ & \begin{tabular}{c|}
4 \\
12 \\
\end{tabular} & $\begin{array}{l}\mathrm{NS} \\
\mathrm{NS} \\
\end{array}$ & $\begin{array}{c}\text { MLH1 } \\
N S \\
\end{array}$ & -Giunti et al., 2009 \\
\hline 13 & $\begin{array}{l}\text { Colorectal cancer } \\
\text { Astrocytoma WHOII } \\
\text { Anaplastic astrocytoma }\end{array}$ & $\begin{array}{l}14 \\
14 \\
13 \\
\end{array}$ & $\frac{\text { Yes }}{\text { Yes }}$ & $\mathrm{MSH} 2$ & Toledano et al., 2009 \\
\hline 14 & $\begin{array}{l}\text { Medulloblastoma } \\
\text { Duodenal adenocarcinoma }\end{array}$ & 16 & Yes & PMS2 & Roy et al., 2009 \\
\hline 15 & Glioblastoma & 3 & Yes & MLH6? & $\begin{array}{l}\text { Viana-Pereira et al., } \\
\text { submitted }\end{array}$ \\
\hline
\end{tabular}

Table 5. Cases reported in the literature with MMR-D associated with brain tumours, including the likely MMR-D cases found in our studies. 
potentially contributing to tumorigenesis (Duval \& Hamelin, 2002). Genes thought to harbour mutations in microsatellites due to the MSI phenotype are commonly designated MSI target genes. There are numerous MSI target genes described, however the relevance of several of them in cancer is not clear-cut (Mori et al., 2001; Woerner et al., 2003). In brain tumours, only a small number of the "classical" mutated MSI target genes have been reported: IGFIIR (Leung et al., 1998) and PTEN (Kanamori et al., 2000), each of them in a single case of MSI high-grade gliomas, and TGF $\beta R I I$, reported in $71 \%$ of samples (Izumoto et al., 1997), although this result was never confirmed (Kanamori et al., 2000; Leung et al., 1998). We identified four additional alterations, not previously reported in brain tumours, all in genes involved in different DNA repair pathways: mutations in the MBD4, DNAPKcs, and MSH6 genes and a polymorphism in MRE11 (Viana-Pereira et al., 2009, 2011).

In summary, MSI is present in a subset of medulloblastomas and paediatric high-grade gliomas associated with molecular alterations distinctive of this phenotype, suggesting a potentially new genetic pathway correlated with the development of these tumours. As MSI is associated in other tumour types to a differential response to chemotherapy, the presence of MSI even in a small subset of brain tumours may have important translational implications in these extraordinarily treatment refractory malignancies.

\section{References}

Aaltonen, L.A., Peltomaki, P., Mecklin, J.P., et al. (1994). Replication errors in benign and malignant tumors from hereditary nonpolyposis colorectal cancer patients. Cancer Research. Vol.54, No.7, pp. 1645-1648, ISSN 0008-5472

Agostini, M., Tibiletti, M.G., Lucci-Cordisco, E., et al. (2005). Two PMS2 mutations in a Turcot syndrome family with small bowel cancers. American Journal of Gastroenterology. Vol.100, No.8, pp. 1886-1891, ISSN 0002-9270

Aldosari, N., Bigner, S.H., Burger, P.C., et al. (2002). MYCC and MYCN oncogene amplification in medulloblastoma. A fluorescence in situ hybridization study on paraffin sections from the Children's Oncology Group. Archives of Pathology $\mathcal{E}$ Laboratory Medicine. Vol.126, No.5, pp. 540-544, ISSN 0003-9985

Alonso, M., Hamelin, R., Kim, M., et al. (2001). Microsatellite instability occurs in distinct subtypes of pediatric but not adult central nervous system tumors. Cancer Research. Vol.61, No.5, pp. 2124-2128, ISSN 0008-5472

Amariglio, N., Friedman, E., Mor, O., et al. (1995). Analysis of microsatellite repeats in pediatric brain tumors. Cancer Genetics and Cytogenetics. Vol.84, No.1, pp. 56-59, ISSN 0165-4608

Arana, M.E. \& Kunkel, T.A. (2010). Mutator phenotypes due to DNA replication infidelity. Seminars in Cancer Biology. Vol.20, No.5, pp. 304-311, ISSN 1044-579X

Baldwin, R.T. \& Preston-Martin, S. (2004). Epidemiology of brain tumors in childhood - a review. Toxicology and Applied Pharmacology. Vol.199, No.2, pp. 118-131, ISSN 0041$008 \mathrm{X}$

Balss, J., Meyer, J., Mueller, W., Korshunov, A., Hartmann, C., \& von Deimling, A. (2008). Analysis of the IDH1 codon 132 mutation in brain tumors. Acta Neuropathologica. Vol.116, No.6, pp. 597-602, ISSN 0001-6322

Barrow, J., Adamowicz-Brice, M., Cartmill, M., et al. (2011). Homozygous loss of ADAM3A revealed by genome-wide analysis of pediatric high-grade glioma and diffuse intrinsic pontine gliomas. Neuro Oncology. Vol.13, No.2, pp. 212-222, ISSN 1522-8517 
Bax, D.A., Mackay, A., Little, S.E., et al. (2010). A distinct spectrum of copy number aberrations in pediatric high grade gliomas. Clinical Cancer Research. Vol.16, No.13, pp. 3368-3377, ISSN 1078-0432

Beroukhim, R., Getz, G., Nghiemphu, L., et al. (2007). Assessing the significance of chromosomal aberrations in cancer: methodology and application to glioma. Proc Natl Acad Sci U S A. Vol.104, No.50, pp. 20007-20012, ISSN 1091-6490

Biegel, J.A., Janss, A.J., Raffel, C., et al. (1997). Prognostic significance of chromosome 17p deletions in childhood primitive neuroectodermal tumors (medulloblastomas) of the central nervous system. Clinical Cancer Research. Vol.3, No.3, pp. 473-478, ISSN 1078-0432

Bigner, S.H., Mark, J., Friedman, H.S., Biegel, J.A., \& Bigner, D.D. (1988). Structural chromosomal abnormalities in human medulloblastoma. Cancer Genetics and Cytogenetics. Vol.30, No.1, pp. 91-101, ISSN 0165-4608

Boland, C.R., Koi, M., Chang, D.K., \& Carethers, J.M. (2008). The biochemical basis of microsatellite instability and abnormal immunohistochemistry and clinical behavior in Lynch syndrome: from bench to bedside. Familial Cancer. Vol.7, No.1, pp. 41-52, ISSN 1389-9600

Bondy, M.L., Scheurer, M.E., Malmer, B., et al. (2008). Brain tumor epidemiology: Consensus from the Brain Tumor Epidemiology Consortium. Cancer. Vol.113, No.7, pp. 19531968, ISSN 0008-543X

Brandes, A.A., Franceschi, E., Tosoni, A., et al. (2009). Adult neuroectodermal tumors of posterior fossa (medulloblastoma) and of supratentorial sites (stPNET). Critical Reviews in Oncology Hematology. Vol.71, No.2, pp. 165-179, ISSN 1040-8428

Bredel, M., Bredel, C., Juric, D., et al. (2005). High-resolution genome-wide mapping of genetic alterations in human glial brain tumors. Cancer Research. Vol.65, No.10, pp. 4088-4096, ISSN 0008-5472

Bromberg, J.E.C. \& van den Bent, M.J. (2009). Oligodendrogliomas: Molecular Biology and Treatment. Oncologist. Vol.14, No.2, pp. 155-163, ISSN 1083-7159

Broniscer, A., Baker, S.J., West, A.N., et al. (2007). Clinical and molecular characteristics of malignant transformation of low-grade glioma in children. Journal of Clinical Oncology. Vol.25, No.6, pp. 682-689, ISSN 0732-183X

Buhard, O., Cattaneo, F., Wong, Y.F., et al. (2006). Multipopulation analysis of polymorphisms in five mononucleotide repeats used to determine the microsatellite instability status of human tumors. Journal of Clinical Oncology. Vol.24, No.2, pp. 241-251, ISSN 0732-183X

Buhard, O., Suraweera, N., Lectard, A., Duval, A., \& Hamelin, R. (2004). Quasimonomorphic mononucleotide repeats for high-level microsatellite instability analysis. Disease Markers. Vol.20, No.4-5, pp. 251-257, ISSN 0278-0240

Burnet, N.G., Jefferies, S.J., Benson, R.J., Hunt, D.P., \& Treasure, F.P. (2005). Years of life lost (YLL) from cancer is an important measure of population burden--and should be considered when allocating research funds. British Journal of Cancer. Vol.92, No.2, pp. 241-245, ISSN 0007-0920

Cahill, D.P., Kinzler, K.W., Vogelstein, B., \& Lengauer, C. (1999). Genetic instability and darwinian selection in tumours. Trends in Cell Biology. Vol.9, No.12, pp. pp. M57M60, ISSN 0962-8924 
Carrie, C., Lasset, C., Alapetite, C., et al. (1994). Multivariate analysis of prognostic factors in adult patients with medulloblastoma. Retrospective study of 156 patients. Cancer. Vol.74, No.8, pp. 2352-2360, ISSN 0008-543X

Central Brain Tumor Registry of the United States [CBTRUS]. (2010). CBTRUS Statistical Report: Primary Brain Tumors in the United States, 2004-2006. In: Central Brain Tumor Registry of the United States, Hinsdale, IL, Available from: www.cbtrus.org

Cheng, Y., Ng, H.K., Zhang, S.F., et al. (1999). Genetic alterations in pediatric high-grade astrocytomas. Human Pathology. Vol.30, No.11, pp. 1284-1290, ISSN 0046-8177

Clifford, S.C., Lusher, M.E., Lindsey, J.C., et al. (2006). Wnt/Wingless pathway activation and chromosome 6 loss characterize a distinct molecular sub-group of medulloblastomas associated with a favorable prognosis. Cell Cycle. Vol.5, No.22, pp. 2666-2670, ISSN 1538-4101

Cogen, P.H. \& McDonald, J.D. (1996). Tumor suppressor genes and medulloblastoma. Journal of Neurooncology. Vol.29, No.1, pp. 103-112, ISSN 0167 -594X

Dams, E., Van de Kelft, E.J., Martin, J.J., Verlooy, J., \& Willems, P.J. (1995). Instability of microsatellites in human gliomas. Cancer Research. Vol.55, No.7, pp. 1547-1549, ISSN 0008-5472

Davis, F.G., Freels, S., Grutsch, J., Barlas, S., \& Brem, S. (1998). Survival rates in patients with primary malignant brain tumors stratified by patient age and tumor histological type: an analysis based on Surveillance, Epidemiology, and End Results (SEER) data, 1973-1991. Journal of Neurosurgery. Vol.88, No.1, pp. 1-10, ISSN 0022-3085

de Leeuw, W.J.F., Dierssen, J., Vasen, H.F.A., et al. (2000). Prediction of a mismatch repair gene defect by microsatellite instability and immunohistochemical analysis in endometrial tumours from HNPCC patients. Journal of Pathology. Vol.192, No.3, pp. 328-335, ISSN 0022-3417

de Tayrac, M., Etcheverry, A., Aurbry, M., et al. (2009). Integrative Genome-Wide Analysis Reveals a Robust Genomic Glioblastoma Signature Associated with Copy Number Driving Changes in Gene Expression. Genes Chromosomes \& Cancer. Vol.48, No.1, pp. 55-68, ISSN 1045-2257

De Rosa, M., Fasano, C., Panariello, L., et al. (2000). Evidence for a recessive inheritance of Turcot's syndrome caused by compound heterozygous mutations within the PMS2 gene. Oncogene. Vol.19, No.13, pp. 1719-1723, ISSN 0950-9232

Dubuc, A.M., Northcott, P.A., Mack, S., Witt, H., Pfister, S., \& Taylor, M.D. (2010). The Genetics of Pediatric Brain Tumors. Current Neurology and Neuroscience Reports. Vol.10, No.3, pp. 215-223, ISSN 1528-4042

Duval, A. \& Hamelin, R. (2002). Genetic instability in human mismatch repair deficient cancers. Annales de Genetique. Vol.45, No.2, pp. 71-75, ISSN 0003-3995

Eckert, A., Kloor, M., Giersch, A., et al. (2007). Microsatellite instability in pediatric and adult high-grade gliomas. Brain Pathology. Vol.17, No.2, pp. 146-150, ISSN 10156305

Ellegren, H. (2004). Microsatellites: simple sequences with complex evolution. Nature Reviews Genetics. Vol.5, No.6, pp. 435-445, ISSN 1471-0056

Ferlay, J., Shin, H.R., Bray, F., Forman, D., Mathers, C., \& Parkin, D.M. (2008). GLOBOCAN 2008. In: Cancer Incidence and Mortality Worldwide: IARC Cancer Base, Available from: http://globocan.iarc.fr 
Fishel, R. \& Kolodner, R.D. (1995). Identification of mismatch repair genes and their role in the development of cancer. Current Opinion in Genetics \& Development. Vol.5, No.3, pp. 382-395, ISSN 0959-437X

Frost, P.J., Laperriere, N.J., Wong, C.S., Milosevic, M.F., Simpson, W.J., \& Pintilie, M. (1995). Medulloblastoma in adults. International Journal of Radiation Oncology Biology Physics. Vol.32, No.4, pp. 951-957, ISSN 0360-3016

Furnari, F.B., Fenton, T., Bachoo, R.M., et al. (2007). Malignant astrocytic glioma: genetics, biology, and paths to treatment. Genes \& Development. Vol.21, No.21, pp. 2683-2710, ISSN 0890-9369

Gardina, P.J., Lo, K.C., Lee, W., Cowell, J.K., \& Turpaz, Y. (2008). Ploidy status and copy number aberrations in primary glioblastomas defined by integrated analysis of allelic ratios, signal ratios and loss of heterozygosity using 500K SNP Mapping Arrays. Bmc Genomics. Vol.9, ISSN 1471-2164

Gilbertson, R.J. \& Ellison, D.W. (2008). The origins of medulloblastoma subtypes. Annual Review of Pathology-Mechanisms of Disease. Vol.3, pp. 341-365, ISSN 1553-4006

Giunti, L., Cetica, V., Ricci, U., et al. (2009). Type A microsatellite instability in pediatric gliomas as an indicator of Turcot syndrome. European Journal of Human Genetics. Vol.17, No.7, pp. 919-927, ISSN 1018-4813

Goel, A., Nagasaka, T., Hamelin, R., \& Boland, C.R. (2010). An optimized pentaplex PCR for detecting DNA mismatch repair-deficient colorectal cancers. PLoS ONE. Vol.5, No.2, pp. e9393

Gottardo, N.G. \& Gajjar, A. (2008). Chemotherapy for Malignant Brain Tumors of Childhood. Journal of Child Neurology. Vol.23, No.10, pp. 1149-1159, ISSN 0883-0738

Hargrave, D. (2009). Paediatric high and low grade glioma: the impact of tumour biology on current and future therapy. British Journal of Neurosurgery. Vol.23, No.4, pp. 351-363, ISSN 0268-8697

Hartmann, C., Meyer, J., Balss, J., et al. (2009). Type and frequency of IDH1 and IDH2 mutations are related to astrocytic and oligodendroglial differentiation and age: a study of 1,010 diffuse gliomas. Acta Neuropathologica. Vol.118, No.4, pp. 469-474, ISSN 0001-6322

Hegde, M.R., Chong, B., Blazo, M.E., et al. (2005). A homozygous mutation in MSH6 causes Turcot syndrome. Clinical Cancer Research. Vol.11, No.13, pp. 4689-4693, ISSN 10780432

Huse, J.T. \& Holland, E.C. (2010). Targeting brain cancer: advances in the molecular pathology of malignant glioma and medulloblastoma. Nature Reviews Cancer. Vol.10, No.5, pp. 319-331, ISSN 1474-175X

Ichimura, K., Pearson, D.M., Kocialkowski, S., et al. (2009). IDH1 mutations are present in the majority of common adult gliomas but rare in primary glioblastomas. Neuro Oncology. Vol.11, No.4, pp. 341-347, ISSN 1522-8517

Imbach, P. (2006). Brain Tumours. In: Pediatric Oncology: A Comprehensive Guide, P. Imbach, T. Kuhne, R. Arceci, (Eds.), pp. 95-117, Springer -Verlag Berlin, ISBN 3-540-20530-6, Heidelberg, Germany

Ionov, Y., Peinado, M.A., Malkhosyan, S., Shibata, D., \& Perucho, M. (1993). Ubiquitous Somatic Mutations in Simple Repeated Sequences Reveal A New Mechanism for Colonic Carcinogenesis. Nature. Vol.363, No.6429, pp. 558-561, ISSN 0028-0836 
Izumoto, S., Arita, N., Ohnishi, T., et al. (1997). Microsatellite instability and mutated type II transforming growth factor-beta receptor gene in gliomas. Cancer Lett. Vol.112, No.2, pp. 251-256,

Jemal, A., Siegel, R., Ward, E., Hao, Y.P., Xu, J.Q., \& Thun, M.J. (2009). Cancer Statistics, 2009. Ca-A Cancer Journal for Clinicians. Vol.59, No.4, pp. 225-249, ISSN 0007-9235

Jiricny, J. (2006). The multifaceted mismatch-repair system. Nature Reviews Molecular Cell Biology. Vol.7, No.5, pp. 335-346, ISSN 1471-0072

Kanamori, M., Kon, H., Nobukuni, T., et al. (2000). Microsatellite instability and the PTEN1 gene mutation in a subset of early onset gliomas carrying germline mutation or promoter methylation of the hMLH1 gene. Oncogene. Vol.19, No.12, pp. 1564-1571, ISSN 0950-9232

Kool, M., Koster, J., Bunt, J., et al. (2008). Integrated genomics identifies five medulloblastoma subtypes with distinct genetic profiles, pathway signatures and clinicopathological features. PLoS One. Vol.3, No.8, pp. e3088.

Korshunov, A., Remke, M., Werft, W., et al. (2010). Adult and pediatric medulloblastomas are genetically distinct and require different algorithms for molecular risk stratification. Journal of Clinical Oncology. Vol.28, No.18, pp. 3054-3060, ISSN 0732$183 X$

Kotliarov, Y., Steed, M.E., Christopher, N., et al. (2006). High-resolution global genomic survey of 178 gliomas reveals novel regions of copy number alteration and allelic imbalances. Cancer Research. Vol.66, No.19, pp. 9428-9436, ISSN 0008-5472

Kreiger, P.A., Okada, Y., Simon, S., Rorke, L.B., Louis, D.N., \& Golden, J.A. (2005). Losses of chromosomes $1 \mathrm{p}$ and $19 \mathrm{q}$ are rare in pediatric oligodendrogliomas. Acta Neuropathologica. Vol.109, No.4, pp. 387-392, ISSN 0001-6322

Kruger, S., Kinzel, M., Walldorf, C., et al. (2008). Homozygous PMS2 germline mutations in two families with early-onset haematological malignancy, brain tumours, HNPCCassociated tumours, and signs of neurofibromatosis type 1. European Journal of Human Genetics. Vol.16, No.1, pp. 62-72, ISSN 1018-4813

Kunkel, T.A. \& Bebenek, K. (2000). DNA replication fidelity. Annual Review of Biochemistry. Vol.69, pp. 497-529

Lamont, J.M., McManamy, C.S., Pearson, A.D., Clifford, S.C., \& Ellison, D.W. (2004). Combined histopathological and molecular cytogenetic stratification of medulloblastoma patients. Clinical Cancer Research. Vol.10, No.16, pp. 5482-5493, ISSN 1078-0432

Lander, E.S., Linton, L.M., Birren, B., et al. (2001). Initial sequencing and analysis of the human genome. Nature. Vol.409, No.6822, pp. 860-921, ISSN 0028-0836

Laughton, S.J., Merchant, T.E., Sklar, C.A., et al. (2008). Endocrine outcomes for children with embryonal brain tumors after risk-adapted craniospinal and conformal primary-site irradiation and high-dose chemotherapy with stem-cell rescue on the SJMB-96 trial. Journal of Clinical Oncology. Vol.26, No.7, pp. 1112-1118, ISSN 0732$183 \mathrm{X}$

Leung, S.Y., Chan, T.L., Chung, L.P., et al. (1998). Microsatellite instability and mutation of DNA mismatch repair genes in gliomas. American Journal of Pathology. Vol.153, No.4, pp. 1181-1188 
Li, G.M. \& Modrich, P. (1995). Restoration of mismatch repair to nuclear extracts of H6 colorectal tumor cells by a heterodimer of human MutL homologs. Proc Natl Acad Sci U S A. Vol.92, No.6, pp. 1950-1954, ISSN 1091-6490

Li, G.M. (2008). Mechanisms and functions of DNA mismatch repair. Cell Research. Vol.18, No.1, pp. 85-98, ISSN 1001-0602

Lipkin, S.M., Wang, V., Jacoby, R., et al. (2000). MLH3: a DNA mismatch repair gene associated with mammalian microsatellite instability. Nature Genetics. Vol.24, No.1, pp. 27-35, ISSN 1061-4036

Ljungman, M. (2010). The DNA damage response--repair or despair? Environmental and Molecular Mutagenesis. Vol.51, No.8-9, pp. 879-889, ISSN 0893-6692

Loeb, L.A. (1991). Mutator phenotype may be required for multistage carcinogenesis. Cancer Research. Vol.51, No.12, pp. 3075-3079, ISSN 0008-5472

Louis, D.N., Ohgaki, H., Wiestler, O.D., \& Cavenee, W.K. (Eds.). (2007). WHO Classification of Tumours of the Central Nervous System, IARC, ISBN 9283224302, Lyon, France

Maher, E.A., Brennan, C., Wen, P.Y., et al. (2006). Marked genomic differences characterize primary and secondary glioblastoma subtypes and identify two distinct molecular and clinical secondary glioblastoma entities. Cancer Research. Vol.66, No.23, pp. 11502-11513, ISSN 0008-5472

Maity, A., Pruitt, A.A., Judy, K.D., \& Phillips, P.C. (2004). Cancer of the Central Nervous System, In: Abeloff's Clinical Oncology, M.D. Abeloff, J.O. Armitage, J.E. Niederhuber, M.B. Kastan, W.G. McKenzie (Eds.), pp. 1357-1362, Elsevier Churchill Livingstone, ISBN 978-0-443-06694-8, Philadelphia, US

Marra, G. \& Jiricny, J. (2005). DNA Mismatch Repair and Colon Cancer. In: Genome Instability in Cancer Development, E.A. Nigg (Ed.), pp. 85-123, Springer Science + Business Media, Inc., ISBN 1-4020-3763-5 New York, US

Martinez, R., Schackert, H.K., Appelt, H., Plaschke, J., Baretton, G., \& Schackert, G. (2005). Low-level microsatellite instability phenotype in sporadic glioblastoma multiforme. Journal of Cancer Research and Clinical Oncology. Vol.131, No.2, pp. 87-93, ISSN 01715216

Martinho, O., Longatto-Filho, A., Lambros, M.B., et al. (2009). Expression, mutation and copy number analysis of platelet-derived growth factor receptor A (PDGFRA) and its ligand PDGFA in gliomas. British Journal of Cancer. Vol.101, No.6, pp. 973-982, ISSN 0007-0920

Maxwell, J.A., Johnson, S.P., McLendon, R.E., et al. (2008). Mismatch repair deficiency does not mediate clinical resistance to temozolomide in malignant glioma. Clinical Cancer Research. Vol.14, No.15, pp. 4859-4868, ISSN 1078-0432

Menko, F.H., Kaspers, G.L., Meijer, G.A., Claes, K., van Hagen, J.M., \& Gille, J.J. (2004). A homozygous MSH6 mutation in a child with cafe-au-lait spots, oligodendroglioma and rectal cancer. Familial Cancer. Vol.3, No.2, pp. 123-127, ISSN 1389-9600

Mori, Y., Yin, J., Rashid, A., et al. (2001). Instabilotyping: comprehensive identification of frameshift mutations caused by coding region microsatellite instability. Cancer Research. Vol.61, No.16, pp. 6046-6049, ISSN 0008-5472

Mulhern, R.K., Merchant, T.E., Gajjar, A., Reddick, W.E., \& Kun, L.E. (2004). Late neurocognitive sequelae in survivors of brain tumours in childhood. Lancet Oncology. Vol.5, No.7, pp. 399-408, ISSN 1470-2045 
Negrini, S., Gorgoulis, V.G., \& Halazonetis, T.D. (2010). Genomic instability - an evolving hallmark of cancer. Nature Reviews Molecular Cell Biology. Vol.11, No.3, pp. 220-228, ISSN 1471-0072

Nicholson, J., Wickramasinghe, C., Ross, F., Crolla, J., \& Ellison, D. (2000). Imbalances of chromosome 17 in medulloblastomas determined by comparative genomic hybridisation and fluorescence in situ hybridisation. Molecular Pathology. Vol.53, No.6, pp. 313-319

Nigg, E.A. (2005). Genome Instability in Cancer Development, Springer Science + Business Media, Inc., ISBN 1-4020-3763-5 New York, US

Nigro, J.M., Misra, A., Zhang, L., et al. (2005). Integrated array-comparative genomic hybridization and expression array profiles identify clinically relevant molecular subtypes of glioblastoma. Cancer Research. Vol.65, No.5, pp. 1678-1686, ISSN 00085472

Oda, S., Maehara, Y., Ikeda, Y., et al. (2005). Two modes of microsatellite instability in human cancer: differential connection of defective DNA mismatch repair to dinucleotide repeat instability. Nucleic Acids Research. Vol.33, No.5, pp. 1628-1636, ISSN 0305-1048

Ohgaki, H. \& Kleihues, P. (2005). Epidemiology and etiology of gliomas. Acta Neuropathologica. Vol.109, No.1, pp. 93-108, ISSN 0001-6322

Ostergaard, J.R., Sunde, L., \& Okkels, H. (2005). Neurofibromatosis von Recklinghausen type I phenotype and early onset of cancers in siblings compound heterozygous for mutations in MSH6. American Journal of Medical Genetics Part A. Vol.139A, No.2, pp. 96-105, ISSN 1552-4825

Parsons, D.W., Jones, S., Zhang, X., et al. (2008). An integrated genomic analysis of human glioblastoma multiforme. Science. Vol.321, No.5897, pp. 1807-1812, ISSN 0036-8075

Paugh, B.S., Qu, C., Jones, C., et al. (2010). Integrated molecular genetic profiling of pediatric high-grade gliomas reveals key differences with the adult disease. Journal of Clinical Oncology. Vol.28, No.18, pp. 3061-3068, ISSN 0732-183X

Pettorini, B.L., Park, Y.S., Caldarelli, M., Massimi, L., Tamburrini, G., \& Di Rocco, C. (2008). Radiation-induced brain tumours after central nervous system irradiation in childhood: a review. Childs Nervous System. Vol.24, No.7, pp. 793-805, ISSN 02567040

Pfister, S., Remke, M., Benner, A., et al. (2009). Outcome prediction in pediatric medulloblastoma based on DNA copy-number aberrations of chromosomes $6 \mathrm{q}$ and 17q and the MYC and MYCN loci. Journal of Clinical Oncology. Vol.27, No.10, pp. 1627-1636, ISSN 0732-183X

Poley, J.W., Wagner, A., Hoogmans, M.M., et al. (2007). Biallelic germline mutations of mismatch-repair genes: a possible cause for multiple pediatric malignancies. Cancer. Vol.109, No.11, pp. 2349-2356, ISSN 0008-543X

Pollack, I.F., Finkelstein, S.D., Burnham, J., et al. (2003). Association between chromosome $1 \mathrm{p}$ and $19 \mathrm{q}$ loss and outcome in pediatric malignant gliomas: results from the CCG945 cohort. Pediatric Neurosurgery. Vol.39, No.3, pp. 114-121, ISSN 1016-2291

Pollack, I.F., Hamilton, R.L., Sobol, R.W., et al. (2010a). IDH1 mutations are common in malignant gliomas arising in adolescents: a report from the Children's Oncology Group. Childs Nervous System. Vol.27, No.1, pp.87-94, ISSN 0256-7040 
Pollack, I.F., Hamilton, R.L., Sobol, R.W., et al. (2010b). Mismatch repair deficiency is an uncommon mechanism of alkylator resistance in pediatric malignant gliomas: a report from the Children's Oncology Group. Pediatric Blood \& Cancer. Vol.55, No.6, pp. 1066-1071, ISSN 1545-5009

Qu, H.Q., Jacob, K., Fatet, S., et al. (2010). Genome-wide profiling using single-nucleotide polymorphism arrays identifies novel chromosomal imbalances in pediatric glioblastomas. Neuro Oncology. Vol.12, No.2, pp. 153-163, ISSN 1522-8517

Rao, S.K., Edwards, J., Joshi, A.D., Siu, I.M., \& Riggins, G.J. (2010). A survey of glioblastoma genomic amplifications and deletions. Journal of Neuro-Oncology. Vol.96, No.2, pp. 169-179, ISSN 0167-594X

Raschle, M., Marra, G., Nystrom-Lahti, M., Schar, P., \& Jiricny, J. (1999). Identification of hMutLbeta, a heterodimer of hMLH1 and hPMS1. Journal of Biological Chemistry. Vol.274, No.45, pp. 32368-32375, ISSN 0021-9258

Reifenberger, G., Blumcke, I., Pietsch, T., \& Paulus, W. (2006). Pathology Classification of Tumors of the Nervous System. In: Neuro-Oncology of CNS Tumors. J.C. Tonn, M. Westphal, J.T. Rutka, S.A. Grossman (Eds.), pp. 5-72, Springer-Verlag Berlin, ISBN 3-540-25833-7, Heidelberg, Germany

Rickert, C.H. \& Paulus, W. (2001). Epidemiology of central nervous system tumors in childhood and adolescence based on the new WHO classification. Child's Nervous System. Vol.17, No.9, pp. 503-511,

Rickert, C.H., Strater, R., Kaatsch, P., et al. (2001). Pediatric high-grade astrocytomas show chromosomal imbalances distinct from adult cases. American Journal of Pathology. Vol.158, No.4, pp. 1525-1532

Roy, S., Raskin, L., Raymond, V.A., Thibodeau, S.N., Mody, R.J., \& Gruber, S.B. (2009). Pediatric Duodenal Cancer and Biallelic Mismatch Repair Gene Mutations. Pediatric Blood \& Cancer. Vol.53, No.1, pp. 116-120, ISSN 1545-5009

Sanson, M., Marie, Y., Paris, S., et al. (2009). Isocitrate dehydrogenase 1 codon 132 mutation is an important prognostic biomarker in gliomas. Journal of Clinical Oncology. Vol.27, No.25, pp. 4150-4154, ISSN 0732-183X

Sarkar, C., Deb, P., \& Sharma, M.C. (2005). Recent advances in embryonal tumours of the central nervous system. Childs Nervous System. Vol.21, No.4, pp. 272-293, ISSN 02567040

Schiffman, J.D., Hodgson, J.G., VandenBerg, S.R., et al. (2010). Oncogenic BRAF mutation with CDKN2A inactivation is characteristic of a subset of pediatric malignant astrocytomas. Cancer Research. Vol.70, No.2, pp. 512-519, ISSN 0008-5472

Schofield, M.J. \& Hsieh, P. (2003). DNA mismatch repair: molecular mechanisms and biological function. Annual Review of Microbiology. Vol.57, pp. 579-608

Scott, R.H., Mansour, S., Pritchard-Jones, K., Kumar, D., MacSweeney, F., \& Rahman, N. (2007). Medulloblastoma, acute myelocytic leukemia and colonic carcinomas in a child with biallelic MSH6 mutations. Nature Clinical Practice Oncology. Vol.4, No.2, pp. 130-134, ISSN 1743-4254

Shah, S.N., Hile, S.E., \& Eckert, K.A. (2010). Defective mismatch repair, microsatellite mutation bias, and variability in clinical cancer phenotypes. Cancer Research. Vol.70, No.2, pp. 431-435, ISSN 0008-5472 
Silber, J.H., Radcliffe, J., Peckham, V., et al. (1992). Whole-brain irradiation and decline in intelligence: the influence of dose and age on IQ score. Journal of Clinical Oncology. Vol.10, No.9, pp. 1390-1396, ISSN 0732-183X

Smith, J.S., Alderete, B., Minn, Y., et al. (1999). Localization of common deletion regions on $1 \mathrm{p}$ and $19 \mathrm{q}$ in human gliomas and their association with histological subtype. Oncogene. Vol.18, No.28, pp. 4144-4152, ISSN 0950-9232

Smith, J.S., Perry, A., Borell, T.J., et al. (2000). Alterations of chromosome arms $1 p$ and $19 q$ as predictors of survival in oligodendrogliomas, astrocytomas, and mixed oligoastrocytomas. Journal of Clinical Oncology. Vol.18, No.3, pp. 636-645, ISSN 0732$183 X$

Sobrido, M.J., Pereira, C.R., Barros, F., Forteza, J., Carracedo, A., \& Lema, M. (2000). Low frequency of replication errors in primary nervous system tumours. Journal of Neurology, Neurosurgery \& Psychiatry. Vol.69, No.3, pp. 369-375, ISSN 1468-330X

Steichen-Gersdorf, E., Baumgartner, M., Kreczy, A., Maier, H., \& Fink, F.M. (1997). Deletion mapping on chromosome 17p in medulloblastoma. British Journal of Cancer. Vol.76, No.10, pp. 1284-1287, ISSN 0007-0920

Stewart, E.S. \& Cohen, D.G. (1998). Central nervous system tumors in children. Seminars in Oncology Nursing. Vol.14, No.1, pp. 34-42, ISSN 0749-2081

Taylor, M.D. (2006). Medulloblastoma, In: Neuro-Oncology of CNS Tumors. J.C. Tonn, M. Westphal, J.T. Rutka, S.A. Grossman (Eds.), pp. 462-469, Springer-Verlag Berlin, ISBN 3-540-25833-7, Heidelberg, Germany

The Cancer Genome Atlas Research Network [TCGA]. (2008). Comprehensive genomic characterization defines human glioblastoma genes and core pathways. Nature. Vol.455, No.7216, pp. 1061-1068, ISSN 0028-0836

Thompson, M.C., Fuller, C., Hogg, T.L., et al. (2006). Genomics identifies medulloblastoma subgroups that are enriched for specific genetic alterations. Journal of Clinical Oncology. Vol.24, No.12, pp. 1924-1931, ISSN 0732-183X

Toledano, H., Goldberg, Y., Kedar-Barnes, I., et al. (2009). Homozygosity of MSH2 c.1906G-$>\mathrm{C}$ germline mutation is associated with childhood colon cancer, astrocytoma and signs of Neurofibromatosis type I. Familial Cancer. Vol.8, No.3, pp. 187-194, ISSN 1389-9600

Tomlinson, F.H., Jenkins, R.B., Scheithauer, B.W., et al. (1994). Aggressive medulloblastoma with high-level N-myc amplification. Mayo Clinic Proceedings. Vol.69, No.4, pp. 359365, ISSN 0025-6196

Ullrich, N.J. (2008). Inherited Disorders As A Risk Factor and Predictor of Neurodevelopmental Outcome in Pediatric Cancer. Developmental Disabilities Research Reviews. Vol.14, No.3, pp. 229-237, ISSN 1940-5510

Umar, A., Boland, C.R., Terdiman, J.P., et al. (2004). Revised Bethesda Guidelines for hereditary nonpolyposis colorectal cancer (Lynch syndrome) and microsatellite instability. Journal of the National Cancer Institute. Vol.96, No.4, pp. 261-268, ISSN 0027-8874

Vagner-Capodano, A.M., Zattara-Cannoni, H., Gambarelli, D., et al. (1994). Detection of $\mathrm{i}(17 \mathrm{q})$ chromosome by fluorescent in situ hybridization (FISH) with interphase nuclei in medulloblastoma. Cancer Genetics and Cytogenetics. Vol.78, No.1, pp. 1-6, ISSN 0165-4608 
van den Bent, M.J., Reni, M., Gatta, G., \& Vecht, C. (2008). Oligodendroglioma. Critical Reviews in Oncology/Hematology. Vol.66, No.3, pp. 262-272, ISSN 1040-8428

Venkatesan, R.N. \& Loeb, L.A. (2005). The Multiplicity of Mutations in Human Cancers. In: Genome Instability in Cancer Development, E.A. Nigg (Ed.), pp. 3-17, Springer Science + Business Media, Inc., ISBN 1-4020-3763-5 New York, US

Viana-Pereira, M., Almeida, I., Sousa, S., et al. (2009). Analysis of microsatellite instability in medulloblastoma. Neuro Oncology. Vol.11, No.5, pp. 458-467, ISSN 1522-8517

Viana-Pereira, M., Lee, A., Popov, S., et al. (2010). Microsatellite Instability in Pediatric High Grade Glioma is Associated with Genomic Profile and Differential Target Gene Inactivation. PLoS ONE. Vol.6, No.5, pp.e20588

Vladimirova, V., Denkhaus, D., Soerensen, N., Wagner, S., Wolff, J.E., \& Pietsch, T. (2007). Low level of microsatellite instability in paediatric malignant astrocytomas. Neuropathology and Applied Neurobiology. Vol.34, No.5, pp. 547-554, ISSN 0305-1846

Wagner, A., Barrows, A., Wijnen, J.T., et al. (2003). Molecular analysis of hereditary nonpolyposis colorectal cancer in the United States: high mutation detection rate among clinically selected families and characterization of an American founder genomic deletion of the MSH2 gene. American Journal of Human Genetics. Vol.72, No.5, pp. 1088-1100, ISSN 0002-9297

Wang, Q., Lasset, C., Desseigne, F., et al. (1999). Neurofibromatosis and early onset of cancers in hMLH1-deficient children. Cancer Research. Vol.59, No.2, pp. 294-297, ISSN 0008-5472

Watanabe, T., Nobusawa, S., Kleihues, P., \& Ohgaki, H. (2009). IDH1 mutations are early events in the development of astrocytomas and oligodendrogliomas. American Journal of Pathology. Vol.174, No.4, pp. 1149-1153

Weingart, J.D., McGirt, M.J., \& Brem, H. (2006). High-Grade Astrocytoma/Glioblastoma. No.6, pp. 128-138,

Woerner, S.M., Benner, A., Sutter, C., et al. (2003). Pathogenesis of DNA repair-deficient cancers: a statistical meta-analysis of putative Real Common Target genes. Oncogene. Vol.22, No.15, pp. 2226-2235, ISSN 0950-9232

Wong, K.K., Tsang, Y.T.M., Chang, Y.M., et al. (2006). Genome-wide allelic imbalance analysis of pediatric gliomas by single nucleotide polymorphic allele array. Cancer Research. Vol.66, No.23, pp. 11172-11178, ISSN 0008-5472

Wong, Y.F., Cheung, T.H., Lo, K.W., et al. (2006). Detection of microsatellite instability in endometrial cancer: advantages of a panel of five mononucleotide repeats over the National Cancer Institute panel of markers. Carcinogenesis. Vol.27, No.5, pp. 951955, ISSN 0143-3334

Wrensch, M., Fisher, J.L., Schwartzbaum, J.A., Bondy, M., Berger, M., \& Aldape, K.D. (2005). The molecular epidemiology of gliomas in adults. Neurosurgical Focus. Vol.19, No.5, pp. E5, ISSN 1092-0684

Yan, H., Parsons, D.W., Jin, G., et al. (2009). IDH1 and IDH2 mutations in gliomas. New England Journal of Medicine. Vol.360, No.8, pp. 765-773, ISSN 0028-4793

Zarghooni, M., Bartels, U., Lee, E., et al. (2010). Whole-genome profiling of pediatric diffuse intrinsic pontine gliomas highlights platelet-derived growth factor receptor alpha and poly (ADP-ribose) polymerase as potential therapeutic targets. Journal of Clinical Oncology. Vol.28, No.8, pp. 1337-1344, ISSN 0732-183X 


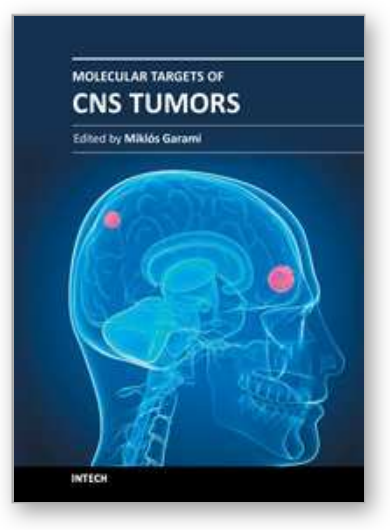

\author{
Molecular Targets of CNS Tumors \\ Edited by Dr. Miklos Garami
}

ISBN 978-953-307-736-9

Hard cover, 674 pages

Publisher InTech

Published online 22, September, 2011

Published in print edition September, 2011

Molecular Targets of CNS Tumors is a selected review of Central Nervous System (CNS) tumors with particular emphasis on signaling pathway of the most common CNS tumor types. To develop drugs which specifically attack the cancer cells requires an understanding of the distinct characteristics of those cells. Additional detailed information is provided on selected signal pathways in CNS tumors.

\title{
How to reference
}

In order to correctly reference this scholarly work, feel free to copy and paste the following:

Marta Viana-Pereira, Chris Jones and Rui M. Reis (2011). Genetic Instability in Paediatric and Adult Brain Tumours, Molecular Targets of CNS Tumors, Dr. Miklos Garami (Ed.), ISBN: 978-953-307-736-9, InTech, Available from: http://www.intechopen.com/books/molecular-targets-of-cns-tumors/genetic-instability-inpaediatric-and-adult-brain-tumours

\section{INTECH}

open science | open minds

\author{
InTech Europe \\ University Campus STeP Ri \\ Slavka Krautzeka 83/A \\ 51000 Rijeka, Croatia \\ Phone: +385 (51) 770447 \\ Fax: +385 (51) 686166 \\ www.intechopen.com
}

\author{
InTech China \\ Unit 405, Office Block, Hotel Equatorial Shanghai \\ No.65, Yan An Road (West), Shanghai, 200040, China \\ 中国上海市延安西路65号上海国际贵都大饭店办公楼405单元 \\ Phone: +86-21-62489820 \\ Fax: +86-21-62489821
}


(C) 2011 The Author(s). Licensee IntechOpen. This chapter is distributed under the terms of the Creative Commons Attribution-NonCommercialShareAlike-3.0 License, which permits use, distribution and reproduction for non-commercial purposes, provided the original is properly cited and derivative works building on this content are distributed under the same license. 